Yusuf Arslan

https://doi.org/10.21278/TOF.44205

ISSN 1333-1124

eISSN 1849-1391

\title{
THE EFFECT OF CRYOGENIC TREATMENT ON THE PUNCH WEAR AND THE HOLE EDGE GEOMETRY
}

\begin{abstract}
Summary
The ball joint parts made of forged steel are quite important in the suspension system. The quality of production of ball joint parts is very important because of their role. Some basic defects can be found in the hole edge form. These defects affect the hole quality of ball joint parts. In this study, the effects of cryogenic processing on the wear of AISI D2 punches and the effects of punch wear on the hole edge geometry of hot forged AISI 1040 steel ball joint parts were investigated. The hole geometry changes are generally associated with punch wear and process parameters. For the purpose of investigation, piercing was carried out using an eccentric press with AISI D2 tool steel punches on $6.0 \mathrm{~mm}$-thick ball joint pieces. The punches were traditionally heat treated. Some of the punches were cryogenic-treated at -145 ${ }^{\circ} \mathrm{C}$ in addition to the conventional heat treatment. Weight loss values were measured to assess the punch wear, and SEM and OM images were analysed. At the end of the industrial piercing process, it was found that the D2 tool steel punch wear decreased with cryogenic process applied and the size changes in the hole edge geometry of the punched 1040 hot forged steel parts turned out to be less marked.
\end{abstract}

Key words: $\quad$ Cryogenic treatment, ball joint, punch wear, edge geometry, AISI D2, AISI 1040

\section{Introduction}

The suspension system carries the vehicle body and allows the driver and passengers to travel comfortably without transmitting all forces to them. This system of a car is used to support its weight under varying road conditions. The system is made of several parts and components, of which the ball joint is an important part (Fig. 1a). The ball joints are located between the wheel assembly and the chassis of the vehicle (Fig. 1b). Though there are many different metals and alloys that can be used, the most common ones are steel and aluminium because of their mechanical properties and price. Most of the components are made of metals and alloys. However, titanium and stainless steel can be used in important designs. Because of the importance of the ball joints, they are usually made of forged steel [1-6]. 


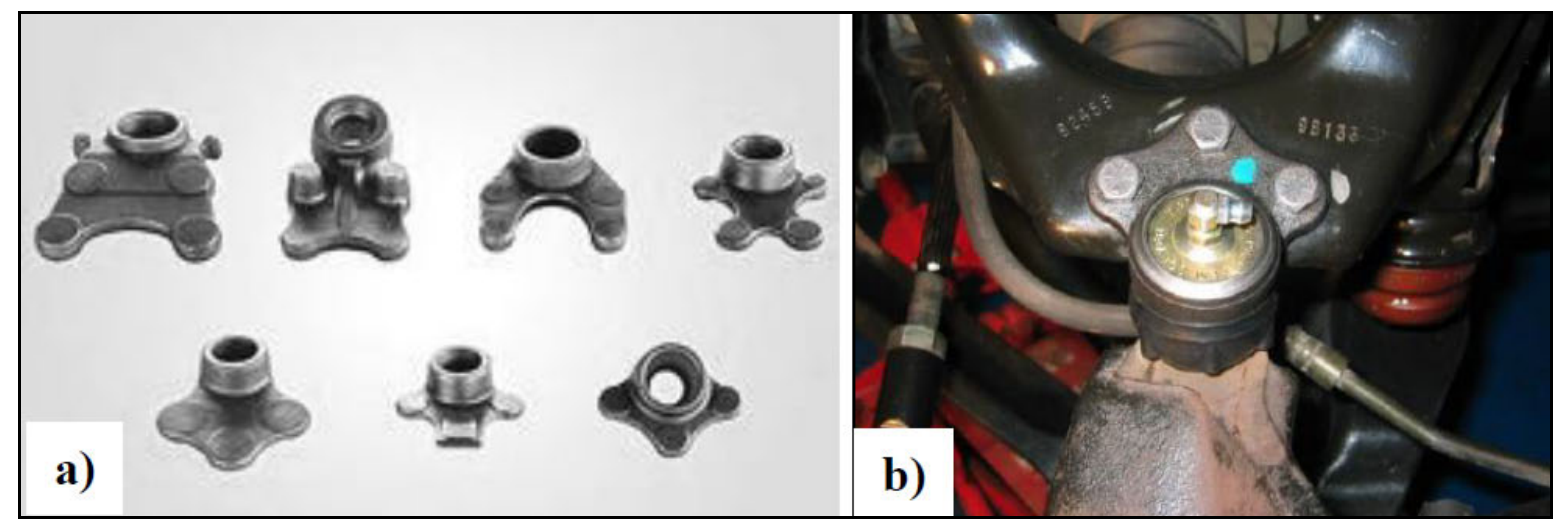

Fig. 1 a) Ball joint parts in various forms, b) A ball joint assembly [5, 6]

Forming with dies has an important place in the production in many sectors such as automotive. Developments in the die design and manufacturing have extended the die lifetime and increased the quality of punching and cutting by enabling a more precise and costeffective production process. The cutting process during punching results in plastic deformation, cutting and breaking stages. According to studies in the relevant literature [6,7], the punching parameters (type, thickness, die clearance, and piercing forces of the workpiece) directly affect the hole form (Fig. 2).

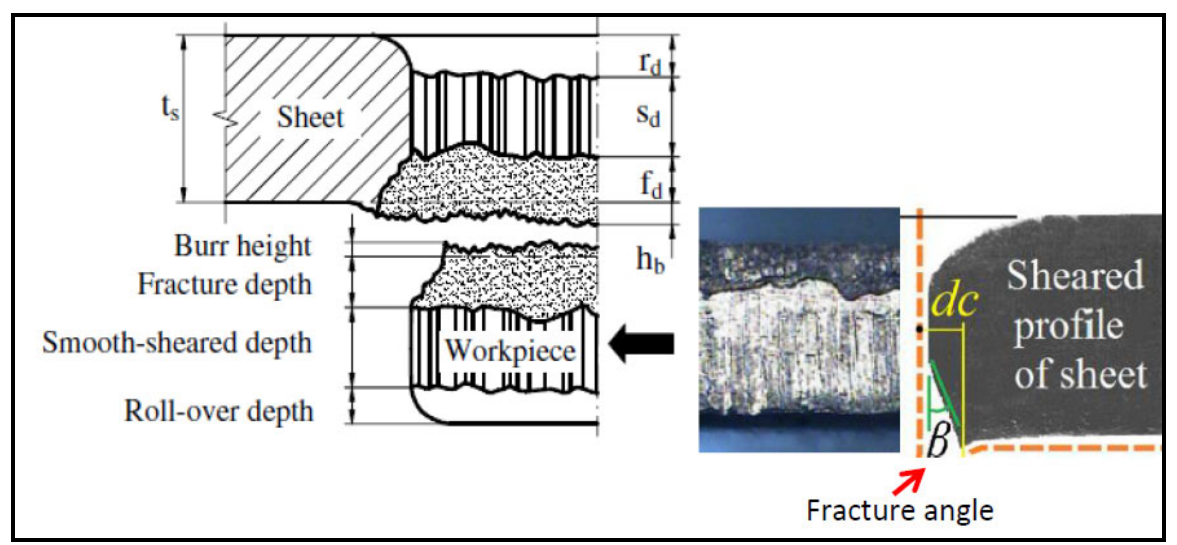

Fig. 2 Different zones of the part edge [8]

Long-lasting dies and punches, less waste, and better quality production are desirable on today's market. The quality of parts is affected by piercing parameters. The punch wear is generally assessed by criteria such as the geometry of the hole edge and the burr height. The rapid and excessive wear of punches can be influenced by the punch material and geometry [9-11]. Due to the mechanical properties of the workpiece and the punch material, excessive stresses and wear occur during the cutting process. These tribological phenomena can be explained as adhesion, transfer between friction elements and fatigue due to micro fractures. In order to maintain the hole quality when these phenomena occur, punches and dies must be replaced at optimum time $[12,13]$. Corroded punches, which adversely affect the hole geometry, should be replaced at the appropriate time to control production costs [14]. A better geometry of the hole edge can be obtained by selecting the punching and cutting parameters of the punch and workpiece materials accordingly [15]. The tool life, wear, cutting clearance, and material thickness have been studied extensively in the relevant literature; however, the hole edge geometry of the products has not been studied yet [16, 17]. Traditional heat treatments are conducted to increase the production speed and the service life of die components made of tool steels (such as high-speed steel) being exposed to heavy loads. After traditional heat treatments, conducted in a way to cool tool steels to room temperature, there is 
still a significant amount of retained austenite in the microstructure. Although the mechanical properties and abrasion resistance are improved by heat treatment, the softer structure adversely affects the wear resistance during production. In recent studies, it can be seen that the traditional heat treatment in combination with cryogenic processes leads to a reduction in the amount of retained austenite in the microstructure of tool steels and increases their wear resistance [17-24].

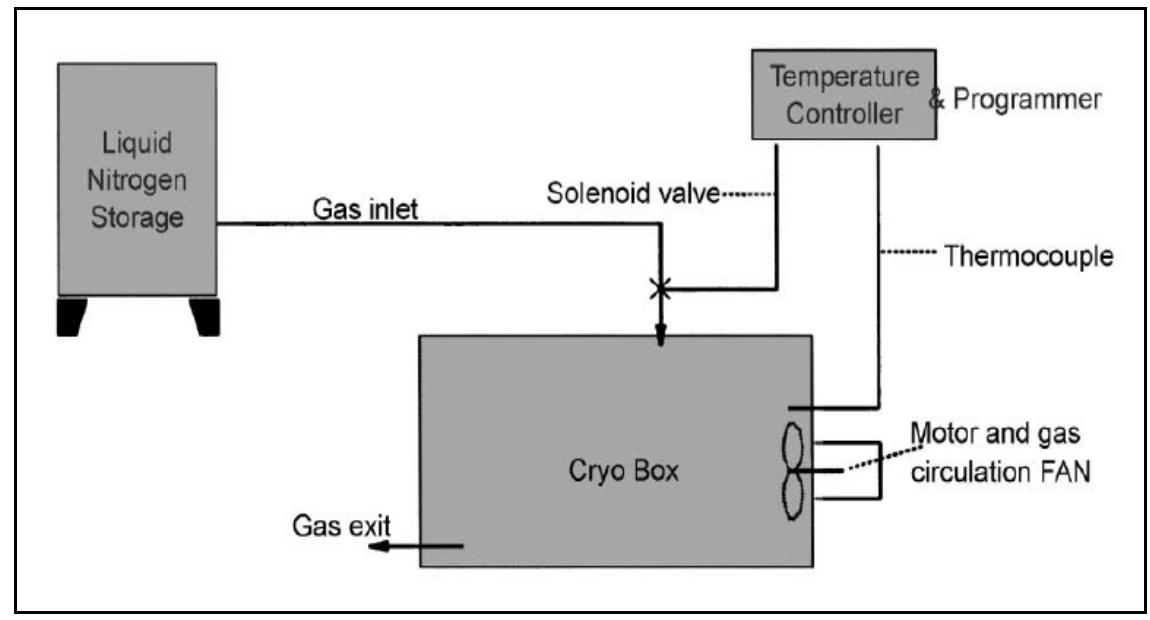

Fig. 3 A cryogenic system [22]

A cryogenic system is shown in Fig. 3. It has been reported that the cryogenic treatment applied after the conventional heat treatment contributes significantly to the wear performance of certain steels. The wear problems of high alloy steels used in important industries such as die industry have been reduced by cryogenic processing $[25,26]$. The application of cryogenic treatment generally results in increased hardness and in the improvement of some of the mechanical properties. After this process, very fine carbide precipitation is observed in the tool steel microstructure with smooth distribution which turns into a martensitic structure and results in high hardness values. These improvements in tool steels have led to decreased wear. Moreover, in contrast to the coating process, the cryogenic process results in fine and dense carbide formation, with carbides uniformly distributed in the matrix structure [27-29].

The cryogenic process is performed once and at a low cost; it is usually carried out for 24 to 36 hours, at temperatures between -80 and $-193{ }^{\circ} \mathrm{C}$, with a cooling rate of 2.5 to $5{ }^{\circ} \mathrm{C} / \mathrm{min}$. The temperature is been gradually brought to ambient temperature by increasing and decreasing temperatures to avoid thermal shocks. There are a lot of studies on machining and cutting tools related to the effect of cryogenic processing. These studies generally focus on high alloy steels and tool steels [30-34]. However, no research has been conducted on the AISI 1040 hot forged steel ball joints and on cryogenically treated AISI D2 tool steel punches in industrial applications. Therefore, the effects of cryogenic processing on the wear of the D2 punches and the effects of punch wear on the hole edge geometry of the 1040 hot forged steel ball joint parts were investigated in this study. Moreover, this study has a real time industrial application.

\section{Materials and Methods}

AISI 1040 hot forged steel ball joint parts were used in this study (Fig. 4). The work pieces used in this study were made of 6.0 -mm-thick AISI 1040 hot forged steel. The chemical content and strength values of a hot forged steel ball joint (as provided by the tool supplier) are presented in Table 1 and 2 . The piercing processes were carried out using a 110 ton capacity press machine and 61 strokes per minute. 


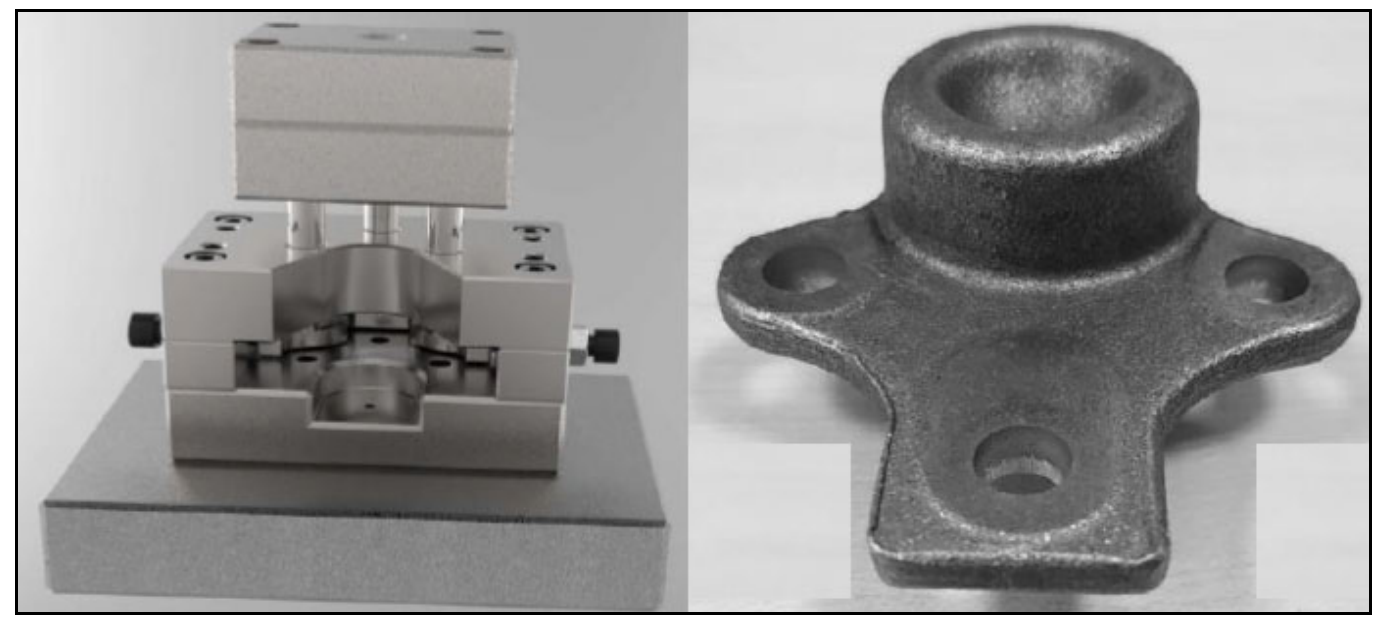

Fig. 4 The die of a ball joint and a ball joint part

The piercing operations were performed under dry conditions in this industrial application. The cutting clearance used in this study was $10 \%$ of the thickness of work pieces. The parts were measured at 1,000th, 5,600th and 9,000th strokes.

Table 1 Chemical composition of AISI 1040 steel

\begin{tabular}{|c|c|c|c|c|c|c|c|c|c|c|}
\hline \multirow{2}{*}{ Elements ( \%) } & $\mathbf{C}$ & $\mathbf{S i}$ & $\mathbf{M n}$ & $\mathbf{P}$ & $\mathbf{S}$ & $\mathbf{A l}$ & $\mathbf{C r}$ & $\mathbf{N i}$ & Mo & Co \\
\cline { 2 - 10 } & 0.427 & 0.209 & 0.630 & 0.011 & 0.0093 & 4.016 & 0.327 & 0.025 & 0.0037 & 0.0021 \\
\hline
\end{tabular}

Table 2 Mechanical properties of AISI 1040 steel

\begin{tabular}{|l|l|l|l|}
\hline $\begin{array}{l}\text { Tensile strength } \\
\left(\mathbf{N} / \mathbf{m m}^{\mathbf{2}}\right)\end{array}$ & $\begin{array}{l}\text { Yield strength } \\
\left(\mathbf{N} / \mathbf{m m}^{\mathbf{2}}\right)\end{array}$ & $\begin{array}{l}\text { Hardness } \\
(\mathbf{H B})\end{array}$ & $\begin{array}{l}\text { Elongation } \\
(\mathbf{\%})\end{array}$ \\
\hline 600 & 361 & 188 & 25 \\
\hline
\end{tabular}

The punches were designed to have $\varnothing 8.5 \times 100 \mathrm{~mm}$. They were made of AISI D2 tool steel. Table 3 presents the chemical composition of that tool steel while Table 4 shows its mechanical properties (provided by the supplier of punches).

Table 3 Chemical composition of AISI D2 cold work tool steel (soft annealed)

\begin{tabular}{|c|c|c|c|c|c|c|c|c|c|c|}
\hline Elements (\%) & $\mathbf{C}$ & $\mathbf{S i}$ & $\mathbf{M n}$ & $\mathbf{P}$ & $\mathbf{S}$ & $\mathbf{C r}$ & $\mathbf{M o}$ & $\mathbf{V}$ & $\mathbf{N i}$ & $\mathbf{C u}$ \\
\cline { 2 - 11 } & 1.590 & 0.360 & 0.500 & 0.025 & 0.006 & 12.430 & 0.870 & 1.000 & 0.240 & 0.080 \\
\hline
\end{tabular}

Table 4 Mechanical properties of AISI D2 cold work tool steel (soft annealed)

\begin{tabular}{|l|l|l|l|}
\hline $\begin{array}{l}\text { Tensile strength } \\
\left(\mathbf{N} / \mathbf{m m}^{2}\right)\end{array}$ & $\begin{array}{l}\text { Compressive yield strength } \\
(\mathbf{a t ~ 6 2} \mathbf{H R C})\left(\mathbf{N} / \mathbf{m m}^{\mathbf{2}}\right)\end{array}$ & $\begin{array}{l}\text { Hardness } \\
(\mathbf{H B})\end{array}$ & $\begin{array}{l}\text { Density } \\
\left(\mathbf{g r} / \mathbf{c m}^{\mathbf{3}}\right)\end{array}$ \\
\hline 940 & 2200 & 225 & 7.67 \\
\hline
\end{tabular}

In this study, punch tools were exposed to deep cryogenic treatment (DCT) after conventional heat treatment (HT). The HT of the D2 tool steel involved hardening and tempering. On the other hand, the DCT of the D2 steel involved hardening and cryogenic treatment before annealing (Fig. 5). DC samples were treated by the conventional heat treatment and deep cryogenic treatment. But, no tempering was performed after the cryogenic treatment. HT and DCT samples were used in the piercing process. The HT of the D2 tool steel was carried out using 4 bar nitrogen in the vacuum heat treatment furnace. The vacuum method is a common process used in industry. In order to eliminate the harmful effects of the 
gases in the air, hardening was conducted in a vacuum atmosphere [35-39]. In the DCT operation, HT samples were gradually cooled to $-145^{\circ} \mathrm{C}$ at a cooling rate of about $5{ }^{\circ} \mathrm{C}$ per minute. The samples were kept at this temperature for 36 hours. After the samples had been gradually reheated to room temperature (at the same rate as in the cooling process), tempering operations were performed. A schematic of the heat treatment of the AISI D2 punches is given in Fig. 5.

A HOYTOM 1003 test machine was used for the evaluation of macro hardness of the samples prepared in accordance with the standards. The main load of $1.5 \mathrm{kN}$ was applied for 20 seconds after a preload of $0.1 \mathrm{kN}$. The average of five measured values was used as the hardness value. The measurements were performed at Rockwell hardness (HRC). The microhardness values were read after applying a $3 \mathrm{~N}$ load for 15 seconds. This process was repeated 10 times. The measurements of Vickers hardness (HV) were performed using a DUROLINEM model measuring device.

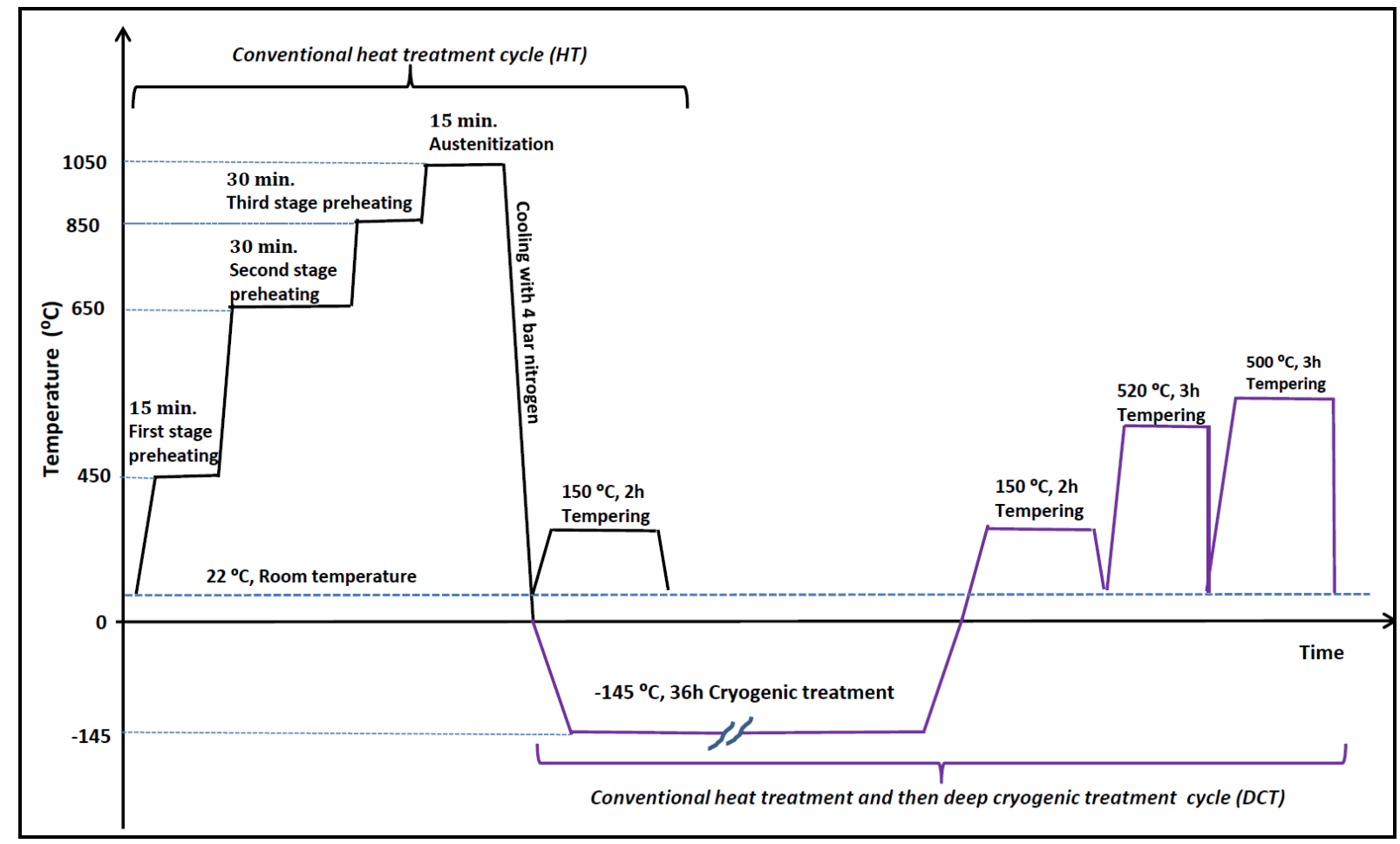

Fig. 5 Schematic of the heat treatment of AISI D2 punches

Microstructural examination was performed using a FEI Quanto FEG 250 scanning electron microscope (SEM). X-Ray Diffraction (XRD) analyses were made in order to determine variations in the microstructure caused by deep cryogenic treatment. Analyses of the retained austenite were conducted according to the ASTM standard E975-13. For the microstructural studies of AISI D2, samples were ground between 80 and 1200 mesh SiC papers according to metallographic preparation standards. Then, they were polished with a polishing solution (diamond paste) and were etched three times with $2 \%$ Nital solution for 10-20 seconds.

Values of the weight loss of the punches required for assessing the wear resistances were measured on a sensitive scale (ELE L 200S Sartorius Laboratory with a sensitivity of $1 \times 10^{-3} \mathrm{~g}$ ). The weight loss values of the punches were measured at 1,000th, 5,600th and 9,000 th strokes. They were measured after cleaning. This process was repeated three times. Further, the degrees of wear of the punches were defined by an Optical Dino-Lite Digital Microscope (OM) Pro2 and by SEM images at the end of the process. 


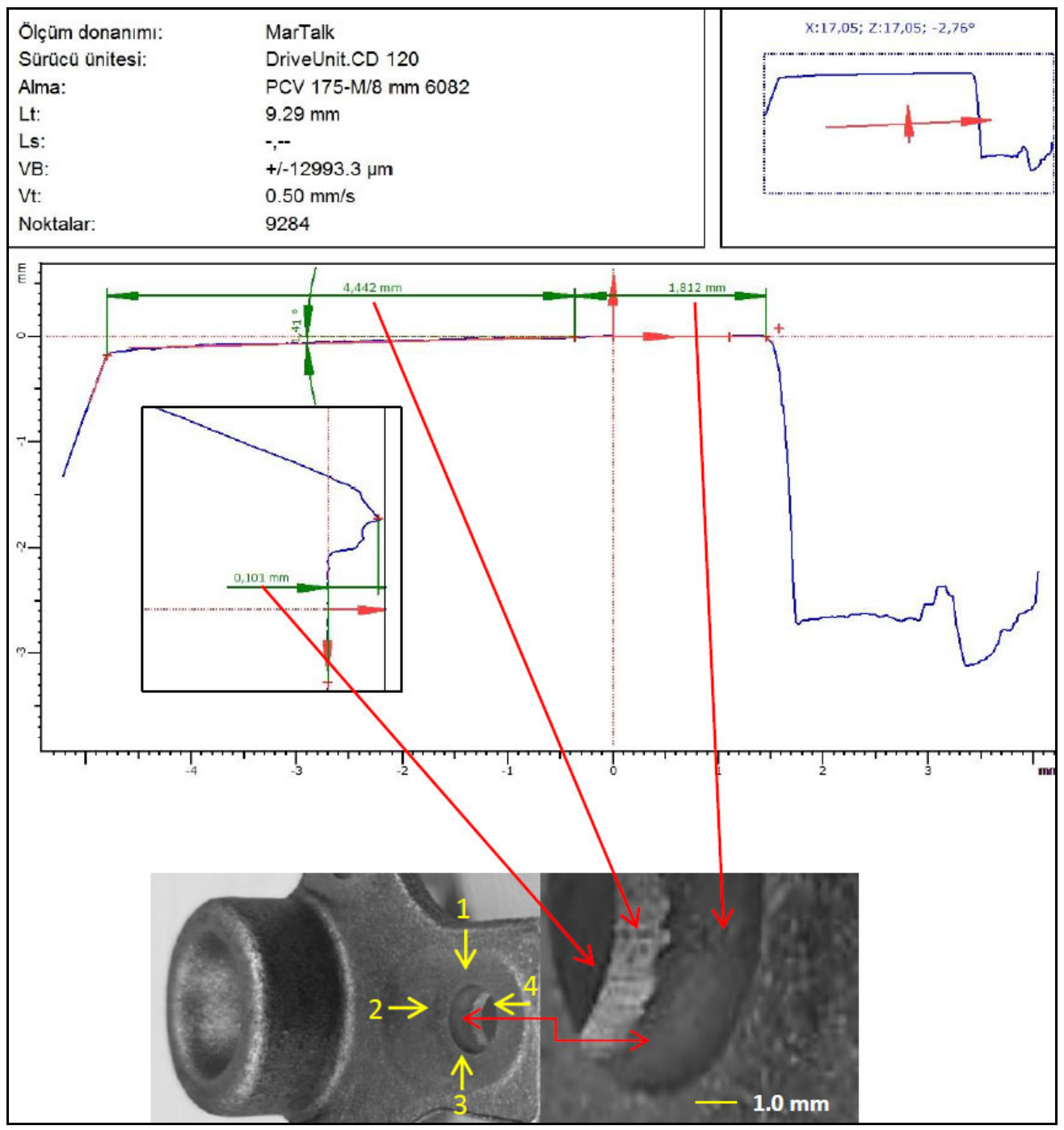

Fig. 6 Outputs of the contour measuring machine

For the measurement of the cut surface holes, a MarSurf CD 120 contour measuring machine with a sensitivity of $1 \times 10^{-3} \mathrm{~mm}$ was used. Thus, no damage was done to the ball joint parts by measurements. The outputs of contour measuring machine are shown in Fig. 6 . About 100 ball joint parts were taken for measurements at the end of each stroke. In order to determine the geometry of the cut surface edges of three ball joint parts selected from 100 samples, four different regions of the holes of each part were measured. The average of the recorded values ( $s_{d}$ smooth-sheared value, $f_{d}$ fracture value, and $h_{b}$ burr value) was obtained. The rollover depth $\left(r_{d}\right)$ is calculated by Equation 1 using the values read from the measuring machine and the value of sheet thickness $\left(t_{s}\right)$ (Fig.6) $[7,24,40]$.

$$
\underline{r}_{\mathrm{d}}=t_{\mathrm{s}}-\left[\left(s_{\mathrm{d}}+f_{\mathrm{d}}\right)-h_{\mathrm{b}}\right]
$$

\section{Results and Discussion}

The effect of cryogenic treatment on hardness values can be seen in Fig. 7. The DCT resulted in an increase in the macro hardness and micro hardness values of AISI D2 tool steel by approximately $3.1 \%\left(\mathrm{HR}_{\mathrm{C}}\right)$ and by $7.99 \%\left(\mathrm{H}_{\mathrm{V}}\right)$, respectively (Fig. 7). Although higher hardness values were obtained for DC samples, their toughness was very poor, which might cause brittle fracture during the piercing process. Thus, DCT samples were preferred to DC samples in application. 


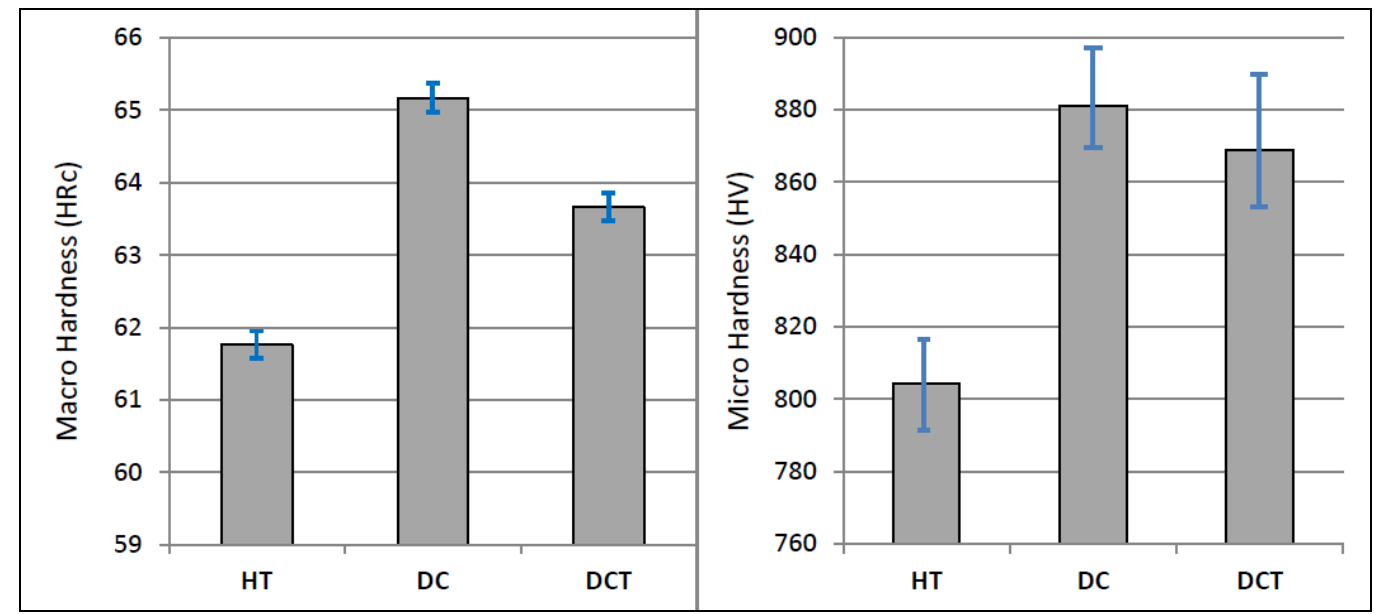

Fig. 7 Macro and microhardness test results of the AISI D2 tool steel

The study showed that the holding time was one of the major factors affecting the material properties and microstructural changes. Similarly, new carbides formed in the microstructure, and the cryogenic process provided a more uniform distribution. Moreover, the austenite retained in a significant amount in the microstructure can be transformed to martensite. These changes in the structure resulted in an increase in the hardness of the samples. Molinera et al. studied the cryogenic process of the M2 and H13 tool steels and found that their hardness increased by about 3\% to $5.8 \%$ [22].

The cryogenic process increased the martensite conversion and led to new thin carbide precipitates (Fig. 8a and b). A decrease in the amount of retained austenite and an increase in fine carbide formation led to increased hardness. Findings in the relevant literature support the results of this study. [27, 30, 34, 38-41].

Figure 8 shows the microstructure of the samples selected to investigate the effects of cryogenic process on the D2 tool steel. In the figure, one can see that the primary carbides (PCs) and secondary carbides (SCs) are more evenly distributed because of the cryogenic process. Moreover, the cryogenic treatment reduced the size of primary particles and increased the volume fraction of secondary carbide particles (Fig. 8a and b). In a number of studies, it has been reported that the cryogenic process not only produces more intense SCs in the microstructure of steels, but also finer PCs [20-23, 26, 27, 37-42].

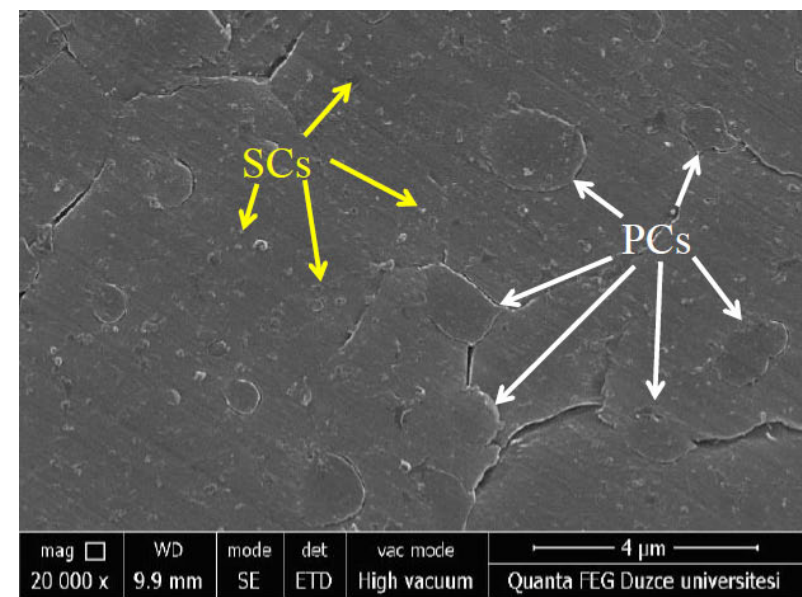

a) $\mathrm{HT}$

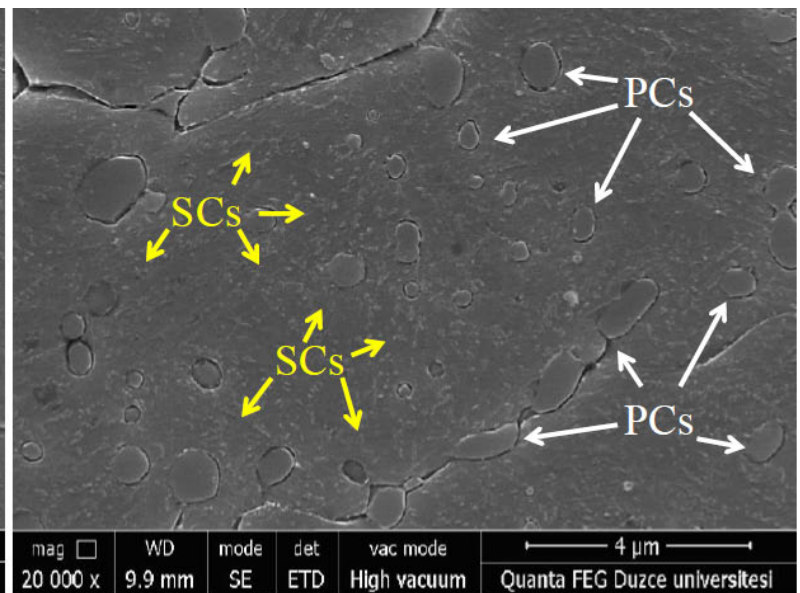

b) DCT

Fig. 8 Microstructure of the AISI D2 tool steel 
Figure 9 shows the results of the XRD analysis performed to determine the amount of retained austenite in the D2 tool steel according to the ASTM standard E975-13 after cryogenic processing. The results show that the amount of retained austenite was dramatically reduced to $1.2 \%$ by the cryogenic treatment; this is due to $92 \%$ martensite transformation resulting from the cryogenic treatment. The results differed only slightly after the DCT process. They show that the deep cryogenic process of the D2 tool steel caused a significant change in its microstructure. Studies in the literature report that the cryogenic process positively affects the wear resistance and enhances the mechanical response of materials due to the change in their microstructure, where the retained austenite provides martensite transformation and newly formed carbides are homogeneously distributed [37, 38, 43-45].

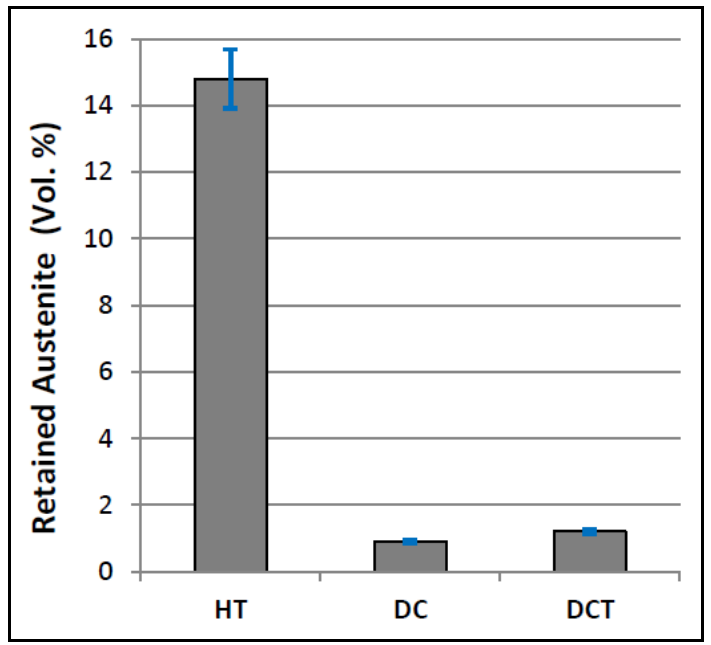

Fig. 9 Retained austenite of AISI D2 tool steels

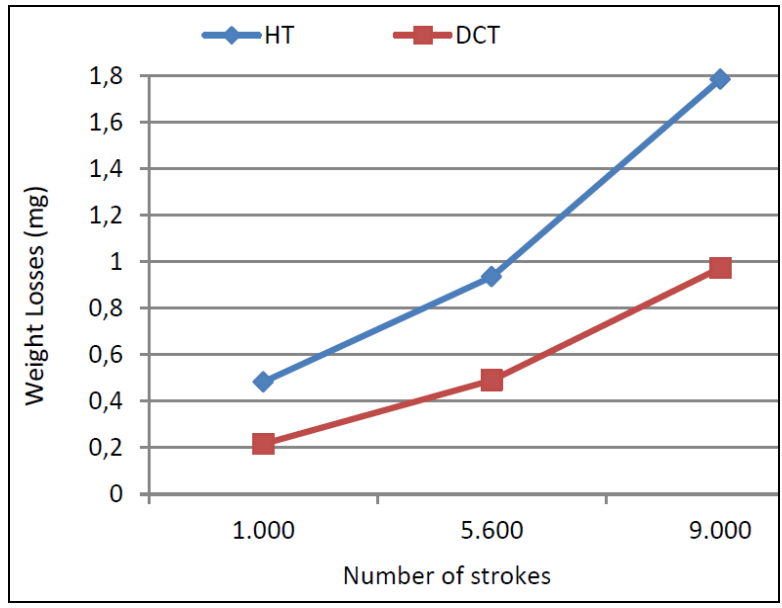

Fig. 10 The relationship between the weight loss and the number of strokes

The weight losses of punches in the piercing stages are shown in Fig. 10. The DCT punches showed less wear in all piercing stages. The HT punches exhibited higher wear weight losses by approximately $83.4 \%$ than the other two groups of punches. It can be said that the cryogenic treatment significantly decreased the weight loss and hence improved the wear resistance and tool life of the tested punches. Similar results are reported in relevant literature $[17-19,26,27,30,33,37]$.

The types of surface wear of the punches were identified by OM and SEM images in all piercing stages. The adhesive and the abrasive wear on punch cutting surfaces, as well as the 
fatigue wear and microcracks were determined through OM and SEM images. There were more microcracks in the HT punches (Fig. 11). Fatigue microcracks were more common at the cutting edge of the HT punches. Fatigue is a progressive and slow-acting failure of components. Fatigue behaviour of materials is affected by various parameters [46, 47]. The abrasive wear was generally observed in the DCT punches; however, adhesive wear was observed on the surfaces of HT punches (Fig. 11). It has been reported that the chromium in the material structure is responsible for the adhesive wear [14].

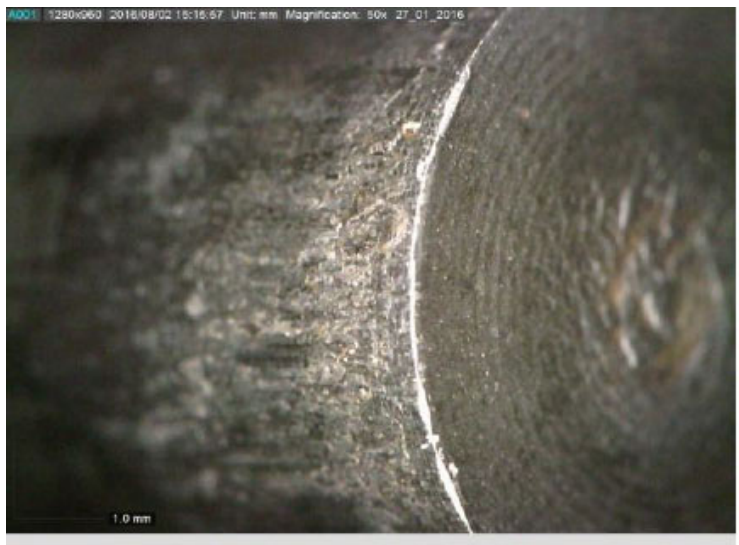

$\mathrm{HT}(\mathrm{OM} \times 50)$

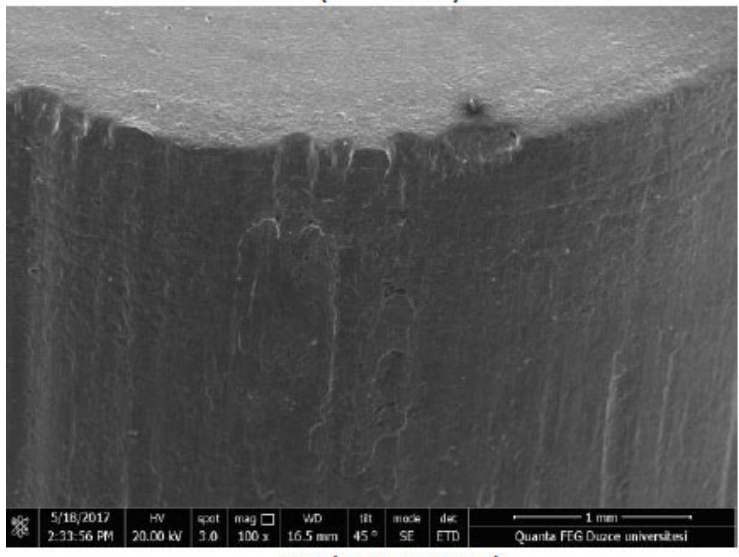

HT (SEM x100)

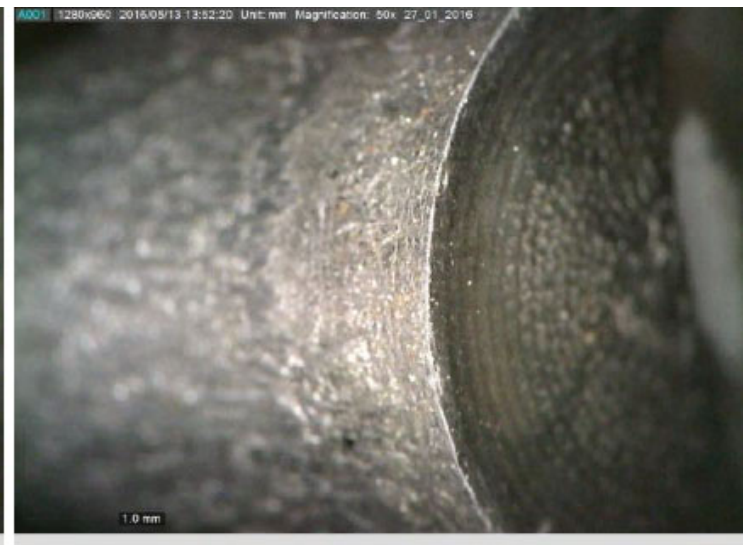

$\mathrm{DCT}(\mathrm{OM} \times 50)$

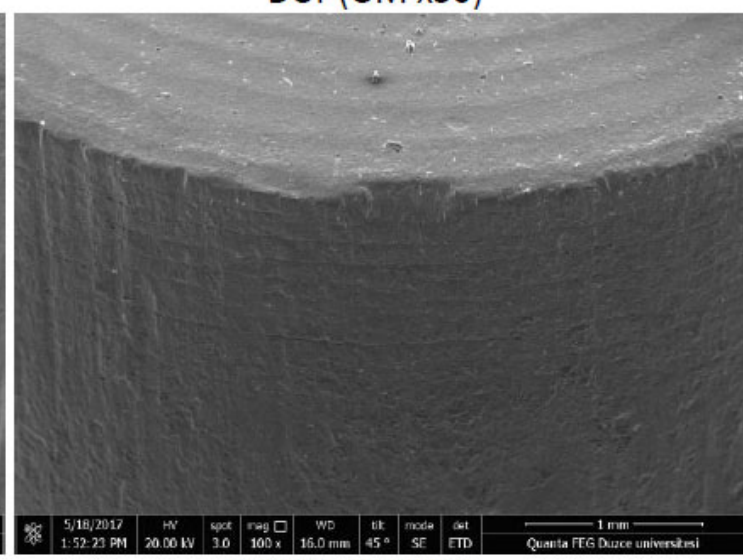

DCT (SEM x100)

Fig. 11 The edge and face wear of the punch at the end of strokes

The effects of cryogenic treatment on the quality of the surface and the hole are shown in Fig 12. It can be seen that the number of strokes affects all parameters. Increased stroke numbers resulted in more severe deterioration. Similarly, the rollover depth and the burr height were significantly reduced by the DCT. However, the smooth-sheared depth and the fracture depth were not affected by the cryogenic treatment. In addition, the average fracture angle increased in the DCT punches.

The important factor in the quality of the hole after piercing is measured by the hole diameter, circularity, rollover depth, fracture depth, burr height, fracture angle, and smoothsheared depth [48-51]. In the holes produced by the HT punches as compared to the DCT punches, the following was observed: the rollover depth, burr height, and fracture angle increased by $54 \%, 27.3 \%$, and $5.1 \%$, respectively, but the fracture depth decreased by $2.5 \%$. The test results show that the cryogenic treatment enhances some mechanical properties and improves the product quality because of a lower degree of wear of punch surfaces. 


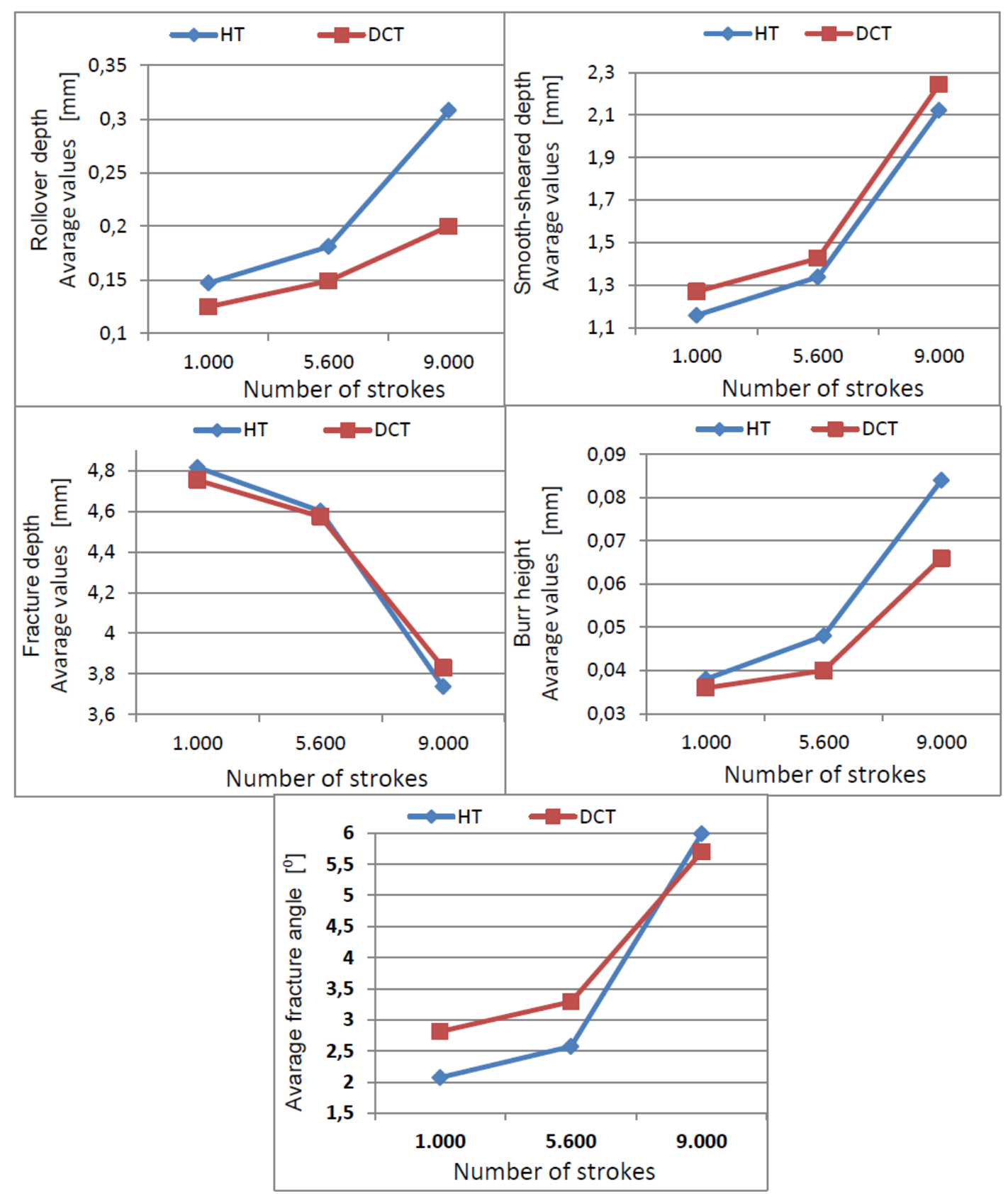

Fig. 12 Average values of geometry of the cut surface of the holes of ball joint parts

\section{Conclusions}

The industrial application of the AISI D2 tool steel punches and the AISI 1040 hot forged steel ball joint parts was tested and the following results were obtained:

1. Hardness values were affected by cryogenic treatment due to the microstructural changes.

2. The amount of retained austenite was dramatically reduced by the cryogenic treatment to $1.2 \%$, which result from $92 \%$ martensite transformation occurring during the cryogenic treatment.

3. The primary and the secondary carbides were more evenly distributed in the microstructure due to the cryogenic process.

4. The DCT punches were less worn in all piercing stages. The wear weight losses of HT punches were approximately $83.4 \%$ higher than of DCT punches. 
5. The abrasive wear was generally observed on the DCT punches; however, adhesive wear was generally observed on the surfaces of the HT punches.

6. In the holes produced by the HT punches as compared to those produced by the DCT punches, the following was observed: the rollover depth, burr height, and fracture angle increased by $54 \%, 27.3 \%$, and $5.1 \%$, respectively, but the fracture depth decreased by $2.5 \%$.

\section{Acknowledgments}

This study was supported by TUBITAK/TEYDEB 1505 University-Industry Cooperation Research Program under the scope of Project Number 5150012.

\section{REFERENCES}

[1] Kothawale, D., Kharde, Y. R., \& Rahata, T. (2013). Analysis of Lower Control Arm in Front Suspension System Using FEA Approach. Analysis, 5(12), 18-23.

[2] Nagarjuna, P., Devi, K. D., \& Subramanian, V. S. (2012). Design and optimization of sheet metal control arm for independent suspension system. International Journal of Engineering Research and Applications, 2(5), 535-539.

[3] Bhushan Kumar, N,. Dayakar. (November 2015). Design and Analysis of Sheet Metal Control Arm. International Journal of Science and Research (IJSR) ISSN (Online): 2319-7064, 4(11), 1241-1248. https://doi.org/10.21275/v4i11.nov151451

[4] M., Sridharan, Dr.S., Balamurugan, (April 2016). Design and Analysis of Lower Control ARM, International Journal of Innovative Research in Science Engineering and Technology (An ISO 3297: 2007 Certified Organization), Vol. 5, Issue 4, 6510-6528.

[5] https://dir.indiamart.com/ludhiana/ball-joint.html/18.08.2018

[6] http://www.cfht.hawaii.edu/ grant/Ball_Joint/BJ_replacement.pdf/18.08.2018.

[7] Akyürek, F., Yaman, K., \& Tekiner, Z. (2017). An Experimental Work on Tool Wear Affected by Die Clearance and Punch Hardness. Arabian Journal for Science and Engineering, 42(11), 4683-4692. https://doi.org/10.1007/s13369-017-2621-0

[8] Mucha, J. (2010). An experimental analysis of effects of various material tool's wear on burr during generator sheets blanking. The International Journal of Advanced Manufacturing Technology, 50(5-8), 495-507. https://doi.org/10.1007/s00170-010-2554-1

[9] Tekiner, Z., Nalbant, M., \& Gürün, H. (2006). An experimental study for the effect of different clearances on burr, smooth-sheared and blanking force on aluminium sheet metal. Materials \& design, 27(10), 11341138. https://doi.org/10.1016/j.matdes.2005.03.013

[10] Lawanwong K., Pornputsiri N., Luangsopapun G. (2011). An investigation of adhesion wear behavior of tool steel on blanking die, 2011 International Conference on Advanced Materials Engineering; IACSIT Press, Singapore, 15:25-30.

[11] P.V.D. Marcondes, A.M. Eto, P.A.C. Beltrăo, P.C. Borges, A smart stamping tool for punching and broaching combination, Journal of Materials Processing Technology, 206(2008) 184-193. https://doi.org/10.1016/j.jmatprotec.2007.12.005

[12] Hatanaka, N., Yamaguchi, K., Takakura, N., \& Iizuka, T. (2003). Simulation of sheared edge formation process in blanking of sheet metals. Journal of Materials Processing Technology, 140(1-3), 628-634. https://doi.org/10.1016/s0924-0136(03)00803-3

[13] Zeng, X. T., Zhang, S., \& Muramatsu, T. (2000). Comparison of three advanced hard coatings for stamping applications. Surface and Coatings Technology, 127(1), 38-42. https://oi.org/10.1016/s02578972(99)00668-4

[14] Myint, M. H., Fuh, J. Y. H., Wong, Y. S., Lu, L., Chen, Z. D., \& Choy, C. M. (2003). Evaluation of wear mechanisms of Y-TZP and tungsten carbide punches. Journal of Materials Processing Technology, 140(1-3), 460-464. https://doi.org/10.1016/s0924-0136(03)00762-3

[15] Fang, G., Zeng, P., \& Lou, L. (2002). Finite element simulation of the effect of clearance on the forming quality in the blanking process. Journal of Materials Processing Technology, 122(2-3), 249-254. https://doi.org/10.1016/s0924-0136(02)00056-0 
[16] Luo, S. Y. (1999). Effect of the geometry and the surface treatment of punching tools on the tool life and wear conditions in the piercing of thick steel plate. Journal of Materials Processing Technology, 88(1-3), 122-133. https://doi.org/10.1016/s0924-0136(98)00375-6

[17] Arslan, Y., Uygur, I., \& Jazdzewska, A. (2015). The effect of cryogenic treatment on microstructure and mechanical response of AISI D3 tool steel punches. Journal of Manufacturing Science and Engineering, 137(3), 034501. https://doi.org/10.1115/1.4029567

[18] Lal, D. M., Renganarayanan, S., \& Kalanidhi, A. (2001). Cryogenic treatment to augment wear resistance of tool and die steels. Cryogenics, 41(3), 149-155. https://doi.org/10.1016/s0011-2275(01)00065-0

[19] Çiçek, A., Kıvak, T., Uygur, I., Ekici, E., \& Turgut, Y. (2012). Performance of cryogenically treated M35 HSS drills in drilling of austenitic stainless steels. The International Journal of Advanced Manufacturing Technology, 60(1-4), 65-73. https://doi.org/10.1007/s00170-011-3616-8

[20] Das, D., Dutta, A. K., \& Ray, K. K. (2009). Influence of varied cryotreatment on the wear behavior of AISI D2 steel. wear, 266(1-2), 297-309. https://doi.org/10.1016/j.wear.2008.07.001

[21] Li, S., Xie, Y., \& Wu, X. (2010). Hardness and toughness investigations of deep cryogenic treated cold work die steel. Cryogenics, 50(2), 89-92. https://doi.org/10.1016/j.cryogenics.2009.12.005

[22] Molinari, A., Pellizzari, M., Gialanella, S., Straffelini, G., \& Stiasny, K. H. (2001). Effect of deep cryogenic treatment on the mechanical properties of tool steels. Journal of materials processing technology, 118(1-3), 350-355. https://doi.org/10.1016/s0924-0136(01)00973-6

[23] Podgornik, B., Leskovšek, V., \& Vižintin, J. (2009). Influence of deep-cryogenic treatment on tribological properties of P/M high-speed steel. Materials and Manufacturing Processes, 24(7-8), 734738. https://doi.org/10.1080/10426910902809339

[24] Arslan, Y., Seker, U., Ozcatalbas, Y., \& Ozdemir, A. (2016). An investigation of the hole diameter and circulirty on the stainless steel sheet perforated via by deep cryogenically treated cold work tool steel punches. Journal of Engineering Research and Applied Science, 5(1), 378-390.

[25] Akhbarizadeh, A., Shafyei, A., \& Golozar, M. A. (2009). Effects of cryogenic treatment on wear behavior of D6 tool steel. Materials \& Design, 30(8), 3259-3264. https://doi.org/10.1016/j.matdes.2008.11.016

[26] Bensely, A., Prabhakaran, A., Lal, D. M., \& Nagarajan, G. (2005). Enhancing the wear resistance of case carburized steel (En 353) by cryogenic treatment. Cryogenics, 45(12), 747-754. https://doi.org/10.1016/j.cryogenics.2005.10.004

[27] Das, D., Ray, K. K., \& Dutta, A. K. (2009). Influence of temperature of sub-zero treatments on the wear behaviour of die steel. Wear, 267(9-10), 1361-1370. https://doi.org/10.1016/j.wear.2008.11.029

[28] Dhokey, N. B., Hake, A., Kadu, S., Bhoskar, I., \& Dey, G. K. (2014). Influence of cryoprocessing on mechanism of carbide development in cobalt-bearing high-speed steel (M35). Metallurgical and Materials Transactions A, 45(3), 1508-1516. https://doi.org/10.1007/s11661-013-2067-2

[29] Uygur, I., Gerengi, H., Arslan, Y., Kurtay, M., (2015) The Effects of cryogenic treatment on the corrosion of AISI D3 steel. Materials Research 18 (3), 569-574. https://doi.org/10.1590/1516-1439.349914

[30] Jaswin, M. A., Lal, D. M., \& Rajadurai, A. (2011). Effect of cryogenic treatment on the microstructure and wear resistance of X45Cr9Si3 and X53Cr22Mn9Ni4N valve steels. Tribology Transactions, 54(3), 341-350. https://doi.org/10.1080/10402004.2010.546033

[31] Isaak, C. J., \& Reitz, W. (2007). The effects of cryogenic treatment on the thermal conductivity of GRCop-84. Materials and Manufacturing Processes, 23(1), 82-91. https://doi.org/10.1080/10426910701524626

[32] Yong, A. Y. L., Seah, K. H. W., \& Rahman, M. (2006). Performance evaluation of cryogenically treated tungsten carbide tools in turning. International Journal of Machine Tools and Manufacture, 46(15), 20512056. https://doi.org/10.1016/j.ijmachtools.2006.01.002

[33] Das, D., Dutta, A. K., \& Ray, K. K. (2008). On the enhancement of wear resistance of tool steels by cryogenic treatment. Philosophical Magazine Letters, 88(11), 801-811. https://doi.org/10.1080/09500830802380788

[34] 34 Das, D., Dutta, A. K., Toppo, V., \& Ray, K. K. (2007). Effect of deep cryogenic treatment on the carbide precipitation and tribological behavior of D2 steel. Materials and Manufacturing Processes, 22(4), 474-480. https://doi.org/10.1080/10426910701235934

[35] http://inductotherm.com.tr/products/horizontal-vacuum-heat-treatment-furnaces/?lang=en/15.07.2018

[36] https://www.metalurji.org.tr/dergi/dergi180/d180_3136.pdf/15.07.2018 
[37] Dhokey, N. B., \& Nirbhavne, S. (2009). Dry sliding wear of cryotreated multiple tempered D-3 tool steel. journal of materials processing technology, 209(3), 1484-1490.

https://doi.org/10.1016/j.jmatprotec.2008.03.069

[38] Amini, K., Akhbarizadeh, A., \& Javadpour, S. (2012). Investigating the effect of holding duration on the microstructure of 1.2080 tool steel during the deep cryogenic heat treatment. Vacuum, 86(10), 1534-1540. https://doi.org/10.1016/j.vacuum.2012.02.013

[39] Jiang, Y., Chen, D., Chen, Z., \& Liu, J. (2010). Effect of cryogenic treatment on the microstructure and mechanical properties of AZ31 magnesium alloy. Materials and Manufacturing Processes, 25(8), 837841. https://doi.org/10.1080/10426910903496862

[40] Bing, G. J. A., \& Wallbank, J. (2008). The effect of using a sprung stripper in sheet metal cutting. Journal of materials processing technology, 200(1-3), 176-184. https://doi.org/10.1016/j.jmatprotec.2007.09.018

[41] Das, D., Dutta, A. K., \& Ray, K. K. (2010). Sub-zero treatments of AISI D2 steel: Part I. Microstructure and hardness. Materials Science and Engineering: A, 527(9), 2182-2193. https://doi.org/10.1016/j.msea.2009.10.070

[42] Akincioğlu, S., Gökkaya, H., \& Uygur, I. (2015). A review of cryogenic treatment on cutting tools. The International Journal of Advanced Manufacturing Technology, 78(9-12), 1609-1627. https://doi.org/10.1007/s00170-014-6755-X

[43] Huang, J. Y., Zhu, Y. T., Liao, X. Z., Beyerlein, I. J., Bourke, M. A., \& Mitchell, T. E. (2003). Microstructure of cryogenic treated M2 tool steel. Materials Science and Engineering: A, 339(1-2), 241244. https://doi.org/10.1016/s0921-5093(02)00165-x

[44] Firouzdor, V., Nejati, E., \& Khomamizadeh, F. (2008). Effect of deep cryogenic treatment on wear resistance and tool life of M2 HSS drill. Journal of materials processing technology, 206(1-3), 467-472. https://doi.org/10.1016/j.jmatprotec.2007.12.072

[45] Akhbarizadeh, A., Amini, K., \& Javadpour, S. (2012). Effect of simultaneous magnetic field and deep cryogenic heat treatment on the microstructure of 1.2080 tool steel. Materials \& Design, 35, 484-490. https://doi.org/10.1016/j.matdes.2011.09.015

[46] Uygur, I., Gulenc, B., (2004). The effect of shielding gas compositions for MIG welding process on mechanical behavior of low carbon steel. Metalurgija 43 (1), 35-40.

[47] Uygur, I., Evans, W., J., Bache, M., Gulenc, B., (2004) The fatigue behaviour of SiC particulate reinforce d 2124 aluminium matrix composites. Metallofizika I Noveishie Tekhnologii, 26 (7), 927-939. https://doi.org/10.1016/j.matdes.2004.09.024

[48] Hernández, J. J., Franco, P., Estrems, M., \& Faura, F. (2006). Modelling and experimental analysis of the effects of tool wear on form errors in stainless steel blanking. Journal of Materials Processing Technology, 180(1-3), 143-150. https://doi.org/10.1016/j.jmatprotec.2006.05.015

[49] Arslan, Y., \& Özdemir, A. (2016). Punch structure, punch wear and cut profiles of AISI 304 stainless steel sheet blanks manufactured using cryogenically treated AISI D3 tool steel punches. The International Journal of Advanced Manufacturing Technology, 87(1-4), 587-599. https://doi.org/10.1007/s12046-017-0598-8

[50] Akıncıoğlu, G., Mendi, F., Çiçek, A., \& Akıncıoğlu, S. (2017). Taguchi optimization of machining parameters in drilling of AISI D2 steel using cryo-treated carbide drills. Sädhanā, 42(2), 213-222. https://doi.org/10.1007/s12046-017-0598-8

[51] Çavuşoğlu, O., \& Gürün, H. (2017). The Relationship of Burr Height and Blanking Force with Clearance in the Blanking Process of AA5754 Aluminium Alloy. Transactions of FAMENA, 41(1), 55-62. https://doi.org/10.21278/tof.41105

$\begin{array}{ll}\text { Submitted: } & 23.01 .2019 \\ \text { Accepted: } & 06.4 .2020\end{array}$
Dr. Yusuf ARSLAN

Department of Mechanical and Metal Technology / Vocational High School, Duzce University, Turkey 